\title{
Nauplii of brine shrimp (Artemia salina) as a potential toxicity testing organism for heavy metals contamination
}

\begin{abstract}
This study was conducted using the $24 \mathrm{~h}$ cultured nauplii of brine shrimp (Artemia salina) as toxicity testing organism exposed to five selected trace elements $(\mathrm{Cu}, \mathrm{Zn}, \mathrm{Cd}, \mathrm{Ni}, \mathrm{Fe})$. The objective was to determine the suitability of A. salina for heavy metals acute toxicity test. The tests were performed after $24 \mathrm{~h} \mathrm{~A}$. salina cysts hatched. The screening tests and definitive tests were conducted in static non-renewal testing solution. Nauplii of A. salina were exposed to different concentration of single-metal solutions and landfill leachates. Mortality of nauplii was used as the end point of the toxicity test. The predicted median lethal concentration (LC50) for each metal was determined by probit analysis. The LC50 values for single-metal exposure were approximately $0.28 \mathrm{ppm} \mathrm{Cu}, 2.47 \mathrm{ppm} \mathrm{Cd}, 2.72 \mathrm{ppm} \mathrm{Zn}$ and $10.23 \mathrm{ppm} \mathrm{Ni}$, respectively. The order of the toxicity level of selected metals to A. salina is $\mathrm{Cu}>\mathrm{Cd}>\mathrm{Zn}>\mathrm{Ni}$. However, the LC50 values for landfill leachates exposure were approximately $0.08 \mathrm{ppm} \mathrm{Cu}, 0.01 \mathrm{ppm} \mathrm{Cd}, 0.11 \mathrm{ppm} \mathrm{Zn}$ and $0.10 \mathrm{ppm} \mathrm{Ni}$, respectively. The order of the toxicity level of selected metals to A. salina is $\mathrm{Cd}>\mathrm{Cu}>\mathrm{Ni}>\mathrm{Zn}$. Lower LC50 values for all metals of landfill leachates proposed there could other factors that potentially induced the decreasing of tolerance level of A. salina nauplii towards these pollutants. Thus, this study proposes nauplii of A. salina as a sensitive bioindicator for heavy metals contamination.
\end{abstract}

Keyword: Artemia salina; Nauphlii; Heavy metals; Toxicity test; Landfill leachates 